KULTURA

i

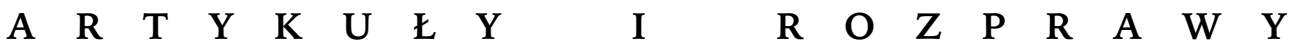

\author{
ALEKSANDRA JASIELSKA \\ Instytut Psychologii Uniwersytetu im. Adama Mickiewicza w Poznaniu \\ RENATA ANNA MAKSYMIUK \\ Instytut Psychologii Uniwersytetu Marii Curie-Skłodowskiej w Lublinie
}

\section{WPEYW INFANTYLIZACJI KULTURY NA ZMIANY W SPOŁECZEŃSTWIE KONSUMPCYJNYM}

Przedstawiciele nauk społecznych i humanistycznych są zdania, iż mówienie o tradycyjnym podziale społeczeństwa opartym na wieku biologicznym jest anachronizmem. Ich zdaniem, liczba przeżytych lat zaczyna mieć coraz mniejsze znaczenie dla określenia na przykład zainteresowań czy potrzeb określonej grupy. Dowodem zacierania się granic może być pojawienie się nowego etapu życiowego nazywanego trzecim wiekiem (third age) (Moen, Spencer 2006). Określenie „trzeci wiek” oznacza czas zaangażowania społeczno-ekonomicznego, jakie przejawia jednostka między przejściem na emeryturę a tzw. czwartym wiekiem (fourth age) (tzw. starość sędziwa). Innym przykładem jest zjawisko „peterpandemonium” polegające na manifestowaniu przez osoby w wieku 18-34 lat zachowań charakterystycznych dla wieku młodzieńczego, na przykład spędzanie czasu w klubach młodzieżowych czy granie na komputerze (Hajdas 2006). Brak społecznych i kulturowych granic między różnymi okresami w życiu człowieka jest wzmacniany przez czynniki, które są pochodną relatywizmu charakterystycznego dla społeczeństwa ponowoczesnego. Należą do nich na przykład zmiany na rynku pracy (brak symbolicznego momentu podjęcia pierwszej pracy, kontynuowanie edukacji po ukończeniu jednego kierunku studiów), wpływ mass mediów (promowanie młodego wyglądu, zachowań charakterystycznych dla osób młodych), rosnące wymagania wobec jednostki (co wynika na przykład z szybkich zmian technologicznych i gwałtownego przyrostu wiedzy) (Bogunia-Borowska 2006).

Zmiany $\mathrm{w}$ postrzeganiu kategorii wiekowych są prawdopodobnie także efektem infantylizacji kulturowej (Bogunia-Borowska 2006). Podążając tym tropem zanik dzieciństwa i powstanie ideologii „nowego starzenia się” (Szlen-

Adres do korespondencji: Aleksandra.Jasielska@amu.edu.pl; renata_maksymiuk@o2.pl 
dak 2005, s. 73) traktuje się jako elementy konstytutywne kultury konsumpcyjnej, w której nie mogą istnieć grupy wiekowe stracone z punktu widzenia pożądanego nade wszystko zysku. Dokonanie takiej diagnozy jest proste, ponieważ wszelkie przetasowania na rynku dóbr konsumpcyjnych mają charakter spektakularny i dotyczą dużych grup osób, w związku z czym dość łatwo poddać je publicznej ocenie. Jednakże znamiona infantylizacji kulturowej można odnaleźć także w innych dziedzinach, na przykład sporcie (Barber 2008), pracy (Bogunia-Borowska 2006) czy seksualności (Zurbriggen i in. 2007). O ile porównywanie wnuczka do dziadka w zakresie na przykład stylu życia, preferencji czy wartości wydaje się jednak nadmiernym uproszczeniem, o tyle zachowania rynkowe, zakupy czy nasilenie chęci posiadania wśród nastolatków i dorosłych można już do siebie odnieść.

Interpretacja przedstawionych zmian stanowi nie lada wyzwanie dla psychologów. Jednak stosowanie wyjaśnień w rodzaju „żyjemy w kulturze konsumpcyjnej” znaczy tyle, co stwierdzenie, że „żyjemy w XXI wieku”. Takie sformułowanie nie buduje bowiem faktycznego zrozumienia zaistniałej sytuacji, ale stwarza jego pozory. Bo jeśli kultura jest konsumpcyjna, a faktycznie jest, to na przykład analiza psychologiczna powinna dotyczyć jednostki, a nie odwoływać się do kultury. Niestety, na razie wydaje się, że w dyskutowanym obszarze psychologowie ustępują nieco pola socjologom czy antropologom kultury oraz - przede wszystkim - pragmatycznym marketerom. Aby wyrównać to zaniedbanie (por. Jasielska 2009), podejmujemy temat konsekwencji infantylizacji kulturowej, która poprzez konsumpcję, marketing i reklamę wpływa na dzieci, młodzieży oraz dorosłych.

\section{INFANTYLIZACJA KULTUROWA}

„Infantylizacja kultury to zjawisko, które wiąże się z cechami charakterystycznymi dotychczas dla dziecka, które stały się uniwersalnym i zaadaptowanym zestawem wartości dla dorosłych $\mathrm{Na}$ ów zestaw składają się następujące cechy: zabawa, reagowanie pod wpływem impulsu, niestabilność emocjonalna [...], nieodpowiedzialność, brak długotrwałych relacji międzyludzkich, krótkoterminowość, zmienność, płynność, koncentracja na własnych potrzebach, przekraczanie granic i rozmaitych zakazów" - jak pisze Małgorzata Bogunia-Borowska (2006, s. 14). W konsekwencji zachodzą równoległe, lustrzane procesy: dziecinnienia dorosłych i doroślenia dzieci. Stosuje się w odniesieniu do nich wiele synonimicznych określeń, jak: emancypacja dziecka, adolescencja dzieci, zanikanie dzieciństwa, komercjalizacja dzieciństwa, antycypacja dorosłości, kult dziecinnienia, kontrolowana regresja, kompresja wieku (Barber 2008; Bogunia-Borowska 2006; Kunkel i in. 2004; Postman 1994; Szlendak 2005). W procesie infantylizacji kulturowej na dziecko zostają nałożone zadania dorosłego, którym nie jest w stanie ono sprostać, wymagające indywidualizmu, samodzielności czy rywalizacji (np. lansowanie nastoletnich modelek w rolach 
dojrzałych kobiet). Zwiększone oczekiwania wobec dzieci (także ich osiągnięć szkolnych) powodują nasilenie stresu i w ten sposób powstaje na przykład potrzeba wprowadzania warsztatów z zakresu radzenia sobie ze stresem już w przedszkolach (Schor 2004). Z kolei osobom dorosłym przekazywana jest stylistyka dostosowana do gustów osób młodszych, jej źródłem jest na przykład kiczowata telewizja (por. Ritzer 2000, s. 127; Szlendak, Kozłowski 2008) czy wydarzenia sportowe promowane „w estetyce dorastających chłopców” (Barber 2008, s. 144). Zanurzeni w kulturze infantylnej dorośli reagują w efekcie pragnieniem zachowania wiecznej młodości.

W dorosłości można też dostrzegać skostnienie, utratę spontaniczności czy schematyczne myślenie i doceniać możliwość „odświeżania” tego etapu życia przez dziecięcą impulsywność, wyobraźnię czy natychmiastową gratyfikację. Jednakże taka interpretacja wydaje się jednowymiarowa. Nie chodzi bowiem tylko o bezrefleksyjne przejmowanie przez dorosłych dziecięcych cech w niezmienionej formie, aż po patologiczny puerylizm. Jeżeli analizujemy kultywowanie dziecięcości w życiu człowieka dorosłego, to trzeba ujmować problem dialektycznie. Faktycznie, istnieją ważne cechy dziecka, które warto zaszczepiać u osób dorosłych, ale nie kosztem odpowiedzialności czy racjonalizmu, jakie niesie dorosłość. Można czerpać z dziecięcych atrybutów, transformować je i asymilować, ale tylko po osiągnięciu dojrzałej tożsamości. Takie ujęcie nawiązuje wprost do postulatów analizy transakcyjnej, dotyczących pozytywnego wykorzystania stanu ja-dziecko w dorosłym życiu (James, Jongeward 2003). Także Erik Erikson (1997, s. 418) twierdził, że „społeczeństwo musi od samego początku [...] zatroszczyć się o nieuniknione pozostałości infantylizmu u wszystkich dorosłych", jednakże chodziło mu raczej o wzmocnienie mechanizmów obronnych człowieka dorosłego skierowanych przeciwko utajonym lękom jego dzieciństwa. Dostrzegał ponadto korzyści, jakie dorosły może czerpać z dziecięcej zabawy (zob. Erikson 1997, rozdz. „Zabawki i rozum”). Jego zdaniem, zabawa w dzieciństwie jest wczesną formą kształtowania zdolności człowieka do radzenia sobie z doświadczeniami. Dzięki niej „człowiek dorosły przeprojektowuje minione doświadczenie do takich rozmiarów, jakie wydają mu się możliwe do zrealizowania" (Erikson 1997, s. 232). Eriksonowskie „opanowywanie rzeczywistości” poprzez zabawę można odnajdywać w wielu rodzajach aktywności człowieka dorosłego, na przykład w twórczości (Nęcka 2001, s. 89), swobodnej eksploracji (Kolańczyk 1999) czy myśleniu w sytuacjach otwartych (Maruszewski 1996, s. 210).

\section{RYNKOWE KONSEKWENCJE INFANTYLIZACJI KULTUROWEJ}

Małgorzata Bogunia-Borowska (2006, s. 15) uważa, że kultura ulega infantylizacji pod wpływem oddziaływań rynkowych. Przeciwnego zdania jest Benjamin Barber (2008, s. 130), według którego to kultura promuje infantylność, z czego rynek instrumentalnie korzysta. Jest to prawdopodobnie spór, 
którego łatwo nie da się rozstrzygnąć. Na potrzeby tych rozważań przyjmijmy, że obydwa obszary - kultura i rynek - są ze sobą ściśle powiązane. Faktem jest, że także analitycy popytu konsumenckiego mówią o zjawisku „zawiłości wiekowej" (age complexity). Zawiłość ta wynika z trudności, jakie nastręcza przyporządkowanie zachowań rynkowych do grup wiekowych i niemożność zastosowania tradycyjnych, branżowych sposobów segmentacji konsumentów (Hajdas 2006). W efekcie poszczególne grupy wiekowe określa się w następujący sposób: dzieci to aktywni rynkowo konsumenci; osoby dorosłe to tzw. kidult (z połączenia angielskich słów kid/dziecko oraz adult/dorosły), czyli konsumenci, który wiodą życie na pograniczu dzieciństwa i dorosłości; seniorzy to w modelu dyfuzji innowacji nabywcy, którzy nie boją się nowości (Hajdas 2006).

Proces zanikania tradycyjnie pojmowanego dzieciństwa i dorosłości jest wzmacniany zabiegami marketingowymi, ponieważ utrzymanie w okresie średniej dorosłości czy starości pędu do konsumowania występującego u młodych pokoleń przynosi zyski. Omawiana tendencja może być także konsekwencją przyjmowania przez społeczeństwa europejskie wzorców zachowań społecznych zaobserwowanych $\mathrm{w}$ społeczeństwie amerykańskim. To właśnie w Stanach Zjednoczonych, na bazie historycznych konfliktów międzypokoleniowych i młodzieńczych buntów, wypromowano wyrafinowaną „antydorosłość” (antiadultism; Schor 2004, s. 51).

\section{INFANTYLNI DOROŚLI}

Opis dorosłych konsumentów, którzy odpowiednio do potrzeb marketingu na powrót stają się dziećmi i przez reklamodawców i marketerów są kreowani na osoby zdziecinniałe i niedojrzałe, za Benjaminem Barberem (2008) można zredukować do trzech archetypicznych dualizmów. Jego zdaniem, istotę infantylizacji oddaje dominacja łatwego nad trudnym, prostego nad złożonym i szybkiego nad powolnym. Analogiczne określenia są stosowane w odniesieniu do wybranych aspektów makdonaldyzacji zachodnich społeczeństw, takich jak: przewidywalność, sprawność, upraszczanie (Ritzer 2000). Poniżej przedstawione zostaną zabiegi w marketingu i reklamie kierowanej do osób dorosłych, które stanowią wykładnię sugerowanej powyżej triady cech.

\section{Dorosły wybiera łatwiejsze}

Kategorię „łatwe”, dominującą nad kategorią „trudne”, konstytuuje niewielki wysiłek poznawczy niezbędny do wypracowania rozwiązania problemu czy zrozumienia go w ogóle (Nęcka, Orzechowski, Szymura 2006, s. 488). Strategia marketingowa bardzo często opiera się na sygnowaniu produktów określeniem „łatwe”. Użycie tego słowa w sloganie reklamowym sprzyja celom promocyjnym, ponieważ denotuje takie znaczenie jak „bezwysiłkowe” czy 
„bezproblemowe” i konotuje to, co „przyjemne”. Oferta rynkowa obfituje więc w „utratę wagi bez wyrzeczeń”, „zdobycie wykształcenia bez trudu”, „ułatwienie kupowania” czy nawet „małżeństwo bez zobowiązań”. Ponadto reklama przedstawia produkty tak, aby ułatwić klientowi ich wybór (Barber 2008). Odbywa się to na dwa sposoby. Pierwszy to pozbawianie produktów szkodliwych substancji: kawa bez kofeiny, śmietana bez tłuszczu czy piwo bezalkoholowe. Drugi sposób to obdarzanie pożytecznymi atrybutami, co paradoksalnie może niekiedy utrudnić odbiór komunikatu, jeżeli $\mathrm{w}$ reklamie używa się określeń naukowych, których potencjalny klient nie rozumie (np. ceramidy czy system TEAD; Maison 1999). Prawdopodobnie ułatwieniu odbioru ma służyć także to, że osoby dorosłe w reklamach reprezentujące ludzi różnych profesji posługują się gwarą młodzieżową: dentysta mówi „Zero ubytków”, mama „I memorkę też”, a zawodowy lektor informuje: „Najbardziej odjechane chwile zakręci wydawca miesięcznika X" (Dolacka-Gasparska 2005). Promowanie braku trudności znajduje odzwierciedlenie w społecznym przyzwoleniu na „pójście na łatwiznę”, na przykład doping w sporcie czy plagiaty prac semestralnych.

\section{Dorosły wybiera prostotę}

Przekładanie „prostoty” nad „złożoność” w przekazach reklamowych sugeruje niewielki poziom komplikacji modelu umysłowego konsumentów. Dorośli stawiani są $\mathrm{w}$ roli nowicjuszy, którzy dysponują nierozbudowanym systemem wiedzy, a nie kompetentnych ekspertów (Nęcka, Orzechowski, Szymura 2006 s. 488). Jednoznacznie dyskredytuje się w ten sposób myślenie człowieka dorosłego, który przecież potrafi dostrzec złożoność problemów, niuanse i wieloznaczności. Zaprzeczający tym prawidłowościom rozwojowym marketing lansujący prostotę jest agresywny, niekiedy aż prostacki. Wiele wydarzeń sportowych czy kulturalnych ulega komercjalizacji, a towarzyszące im powszechnie działania promocyjne (product placement, sponsoring, obecność celebrytów) powodują, że przekształcają się w tzw. reklamorozrywkę. Slogany reklamowe zawierają sformułowania sugerujące związek prostoty z przyjemnością: „I życie stało się proste”, „Masz problem z głowy” czy „Doskonała jakość obrazu i dźwięku w zasięgu Twojej ręki”. Tożsamość konsumenta wyznacza po prostu posiadanie przedmiotów określonej marki czy reklamowanych gadżetów (np. „Wolność bycia sobą” to slogan z reklamy depilatora). W ujęciu symbolicznym prostota jest także elementem dominującego na rynku kultu młodości. Spoty posiłkują się jej synonimami, jak „gładki” (np. „Zmarszczki wyraźnie wygładzone”) czy „napięty” (np. „Przywraca napięcie, jędrność i wyrazisty owal twarzy"). W tendencję tę wpisuje się nieobecność w reklamie osób w wieku senioralnym. Przejawem feerycznego ujęcia prostoty jest obecność $\mathrm{w}$ reklamach dla dorosłych bajkowych bohaterów o jednoznacznych rolach, na przykład dobry-zły, skromny-pyszny, pełniących „archetypowe” funk- 
cje: wroga, ofiary i wybawiciela (Ryłko-Kurpiewska 1997), czy umagicznione zakupy $\mathrm{W}$ nowoczesnym centrum handlowym (Szlendak 2005, s. 61). Wyrazem mentalnej skłonności do prostoty jest tzw. affluenza (od ang. affluence/zamożność, influenza/grypa), czyli grypa bogatych, której jednym z symptomów jest niechęć - związane $z$ nią psychiczne dolegliwości - do kontaktów z czymkolwiek, co miałoby jakikolwiek głębszy sens (zob. Szlendak 2005, s. 89).

\section{Dorosły wybiera szybkość}

Ostatni wymiar — przewaga „szybkiego” nad „powolnym” — to synteza dwóch wcześniej przedstawionych. Egzemplifikacją tego jest rozpatrywana na gruncie psychologii uwagi selektywnej zasada przetargu między szybkością a poprawnością (speed-accurancy trade-off), która mówi, że człowiek może przetwarzać informacje szybko, ale wówczas robi to pobieżnie i popełnia wiele błędów (Nęcka, Orzechowski, Szymura 2006, s. 193). Szybko przetwarza się dane ubogie semantycznie i pobieżne, to jest proste i łatwe. Zbioru takich danych dostarcza się za pośrednictwem wielości mediów elektronicznych, w całodobowym cyklu informacyjnym (Barber 2008). Powszechnie występuje multitasking, czyli jednoczesne korzystanie $z$ wielu mediów czy kanałów komunikacyjnych. Jest to aktywność charakterystyczna dla najmłodszych konsumentów, którą przejmują dorośli. Natychmiastowej komunikacji via internet towarzyszy dynamiczna reklama, na przykład reklama pop-up (czyli nagle pojawiające się okno $z$ reklama) lub marketing wirusowy. W efekcie upowszechniają się takie cechy jak: powierzchowne przetwarzanie docierających treści i trudności z koncentracją nawet na ciekawych rzeczach (Foehr 2006). Są to prawdopodobnie koszty konsumenckiego pośpiechu.

Produkty szybkie utożsamiane są z produktami fast i instat. Prym wiodą w tym względzie jedzenie typu fast food (np. „Danie w 5 minut”) i kosmetyki (np. „Natychmiastowe efekty wygładzenia w 3 dni”). Obrazu dopełniaja usługi wykorzystujące niemożność odraczania gratyfikacji: szybki kredyt, drive bary, ostatnie dni wyprzedaży, „Mówisz - masz” itp. W języku sloganów reklamowych wyrazem przyspieszenia jest stosowanie przymiotników w stopniu najwyższym lub wzmacnianie siły perswazji haseł przez dodanie do nich przedrostków pochodzenia obcego, jak: super, ekstra-, mega-, hiper-, ultra-. Powstają zatem wzmagające zainteresowanie określenia „ultranowoczesne”, „supermodny” czy „meganowe” lub multiplikacje określeń: „Narodziły się nowe pieluszki z nowym obliczem" (Dolacka-Gasparska 2005). Symbolicznym wyrazem akceleracji jest propagowanie w reklamach zwycięstwa na czasem. Wyrazem tego trendu jest oszczędzanie czasu (np. skorzystanie $z$ bankomatu, szybkie randki), cofanie czasu (np. odmładzanie), całodobowość (np. 24-godzinne usługi), przesunięcie w czasie (np. technologia przyszłości), skrótowość (np. akronimizacja mowy). 
Cechy takie jak: łatwość, prostotę i szybkość, można odnaleźć w zabawie. Na rynku zabawek dla dzieci pojawiły się na przykład takie, które ze względu na wyposażenie w elementy elektroniczne określenie są jako interaktywne (Buckleitner 2001). Stosując zabieg marketingowy oparty na „błędzie nadmiernego włączania" (overinclusion) reklamodawcy dla uproszczenia przypisują im cechy zabawek typu smart toys - posiadanie inteligencji czy edukacyjność. Istnieje grupa rodziców, którzy bezrefleksyjnie, z łatwością przyjmują istnienie tzw. wartości dodanej, czyli wartości edukacyjnej w zabawkach pseudointeraktywnych. Zakładają oni, że zabawa przedmiotami o takim charakterze przyspieszy rozwój ich dzieci. Ponadto badanie przeprowadzone wśród rodziców dzieci przedszkolnych z wykorzystaniem dostępnej na rynku zabawki interaktywnej pokazało, że istotna statystycznie większość rodziców deklarowała chęć zakupu zabawki, ponieważ - jak twierdzili — sami chcieliby ją posiadać będąc dziećmi (Jasielska, Kaczmarek 2008).

\section{POWAŻNE DZIECI}

Równolegle do procesu infantylizacji dorosłych zachodzi proces czynienia z dzieci osób bardziej dojrzałych, niż wskazuje na to ich wiek biologiczny. W celu opisu tego zjawiska przez specjalistów od marketingu został ukuty akronim KAGOY (kids are getting older younger; Schor 2004, s. 56). Paweł Kossowski (1999, s. 239) twierdzi, że „...obecność elementów reklam w podkulturze dziecięcej świadczy o [...] wkraczaniu świata dorosłych w świat dzieci, kolonizowaniu dziecięcych zabaw, wyobrażeń, pragnień przez komunikaty stworzone w celach komercyjnych, a nie wychowawczych". Warto przy tym zaznaczyć, że obserwowane zmiany $\mathrm{w}$ stosunku do dzieci nie są nagłe, lecz pojawiają się w konsekwencji długotrwałych zmian społecznych. „Pozycja dziecka zostaje wzmocniona i wyeksponowana $\mathrm{w}$ społeczeństwach postindustrialnych wraz z uzyskaniem przez dzieci statusu konsumenta" - jak pisze Bogunia-Borowska (2006, s. 19). Zacieranie się granic wiekowych wynika $z$ tego, że dla marketerów znaczenie ma nie, kto jest konsumentem, lecz jaką dysponuje siłą nabywczą.

Promowanie dorosłości w zachowaniach dzieci polega zatem przede wszystkim na usytuowaniu ich $\mathrm{w}$ rolach konsumenckich: konsumenta, eksperta, konsultanta i inwestora, do tej pory zarezerwowanych dla osób dorosłych. Oddziaływanie zachowań konsumenckich wynikających z określonej roli jest zwielokrotnione dzięki istnieniu trzech typów rynku. Funkcjonuje tzw. rynek pierwotny (primary market), w ramach którego dzieci same dokonują zakupów, rynek wpływu (influence market), oparty na tym, że dzieci wpływają na innych - przede wszystkim rodziców - by dokonali zakupu, bierze się też pod uwagę oddziaływanie na rynek przyszły (future market) zakładając, że dzieci dorosną i w przyszłości będą mogły dokonywać jeszcze większych zakupów (Comstock, Scharrer 2007; McNeal 1998). 


\section{Dziecko konsument}

Wśród ról dziecka poczesne miejsce zajmuje rola konsumenta, co najpełniej oddają ukute dla potrzeb opisu tego zjawiska określenia: „komercjalizacja dzieciństwa” (Kunkel i in. 2004), „kindermarketing” (por. Jasielska, Maksymiuk 2010) czy „kidzbiz” (Lindstrom 2005). Wynalazki czasów współczesnych to bogata oferta produktów tylko dla młodych konsumentów, na przykład moda dziecięca (Bogunia-Borowska 2006), specjalne strategie marketingowe, na przykład reklama peer-to-peer (Lindstrom 2005), a także rynkowa segmentacja dzieci i młodzieży (Giza-Poleszczuk 2006).

Na rynku pierwotnym dziecko jest pełnoprawnym konsumentem, podejmującym autonomiczne decyzje dotyczące zakupów, podobnie jak osoby dorosłe. Analizy wskazują, że dzieci i młodzież mają siłę nabywczą, dysponują coraz większymi sumami (Gunter, Furnham 1998; Raport IPSOS 2005; Maison, Rudzińska 2009). Większość rodziców dzieci w wieku od 4 do 18 lat (69\%) daje im bowiem kieszonkowe, którym mogą same rozporządzać. Pieniądze otrzymuje 20\% dzieci w wieku 4-6 lat i czterokrotnie więcej, bo 88\%, nastolatków w wieku 15-18 lat. Wysokość otrzymywanej kwoty zależy od wieku dziecka. W Polsce młodsze dzieci dysponują kwotą powyżej 30 zł, starsze ok. 40 zł, a młodzież ok. 80 zł miesięcznie (Raport IPSOS 2008). Badania zakupów pokazują, że dzieci i młodzież przeznaczają swoje pieniądze na słodycze, jedzenie, napoje, książki, komiksy, czasopisma, płyty i kasety, kosmetyki i aktywność w czasie wolnym, jak kino i gry komputerowe, a także na doładowania do telefonów (Giza-Poleszczuk 2006; Raport IPSOS 2008).

$\mathrm{Na}$ rynku wpływu (inaczej rynku wpływowym; por. Jasielska, Maksymiuk 2010) dziecko jest konsumentem latentnym. Nie dokonuje zakupów bezpośrednio, ale oddziałuje w sposób pośredni, przez prośby czy żądania wysuwane pod adresem osób dorosłych. Jest to tzw. czynnik marudy (Szlendak 2005, s. 39) lub w nomenklaturze marketingowej „czynnik jęczenia” (the nag factor) (Halawa 2006, s. 50). Wydaje się, że interakcja między rodzicem a dzieckiem na rynku wpływu przebiega z zachowaniem tradycyjnej roli jednej i drugiej strony. Dziecko $\mathrm{w}$ tej relacji jest zależne od rodzica, a rodzic sam, niezależnie podejmuje decyzję czy spełni dziecięce oczekiwania czy nie. Nakłaniając rodzica do zakupu, dziecko kieruje się takimi cechami produktu, jak reklama, dostępność psychiczna czy estetyka, rodzic zaś rozpatruje zakup racjonalnie w kategoriach możliwości finansowych czy potrzeb. Produkty, na których zakup dzieci mają wpływ, można podzielić na trzy grupy: 1) przedmioty dla dzieci, jak przekąski zabawki, elektronika, ubrania i gadżety związane z dziecięcym hobby; 2) przedmioty do domu, jak meble, elementy wystroju wnętrz, zestawy telewizyjne, zestawy muzyczne, jedzenie i napoje; 3) produkty dla członków rodziny, jak wakacje, samochody, posiłki $\mathrm{w}$ restauracjach czy sprzęt rekreacyjny (McNeal 1992, s. 63-64). Wpływ na zakup produktów dwóch ostatnich grup wskazuje na emancypację dziecka na rynku pośrednim. 
W relacjach dzieci i rodziców podczas zakupów może wystąpić: kupowanie na zamówienie, ustępstwo ze strony rodziców, odmowa prowadząca do konfliktu (Comstock, Scharrer 2007). W tym ostatnim przypadku dziecko może mieć pretensję do rodziców, że nie ulegają prośbom czy żądaniom, ale jego niezadowolenie może także wynikać $z$ faktu, że zakupiony produkt nie spełnia oczekiwań (Buijzen, Valkenburg 2005; Comstock, Scherrer 2007).

\section{Dziecko ekspert i doradca}

Współczesne dzieci i młodzież żyją w warunkach gospodarki wolnorynkowej. Reklama, promocja i inne zabiegi marketingowe są dla nich czymś codziennym i naturalnym. Towarzyszy temu dynamiczny rozwój nowych technologii. Tradycyjne zabawki zostały zastąpione przez gadżety wyposażone w elementy elektroniczne (konsole do gier, komputery, telefony komórkowe itd.) (por. Ranking zabawek 2006), a w przemyśle zabawkarskim obserwuje się zjawisko „kompresji wieku”, które polega na tym, iż zabawkami dla określonej grupy wiekowej zaczynają się bawić coraz młodsze dzieci (Schor 2004). Wśród młodzieży w wieku od 12 do 18 lat z internetu korzysta 96\%, a 90\% ma własny telefon komórkowy (Wenglorz 2006). W konsekwencji młodsze pokolenie ma wyższą kompetencję techniczną czy konsumpcyjną niż dorośli, dzieci i młodzież stają się ekspertami w dziedzinie kupowania czy mediów elektronicznych. Dowiodło tego ogólnopolskie badanie, którego celem było określenie postaw konsumentów wobec reklamy jako narzędzia komunikacji marketingowej (Raport UOKiK 2004). W badaniu wzięli udział dorośli konsumenci $(\mathrm{N}=957)$ oraz ich dzieci w wieku $12-18$ lat $(\mathrm{N}=220)$. Okazało się, że młodzi ludzie są lepiej przystosowani do realiów rynkowych niż ich rodzice. Oznacza to, że na przykład lepiej niż starsi orientują się $\mathrm{w}$ ofercie rynkowej i względnie dobrze znają swoje prawa. Przeprowadzona segmentacja badanych pokazała, że wśród młodych konsumentów dwie trzecie stanowią ci, których można uznać za dobrze zaadaptowanych do warunków konsumpcji, a wśród dorosłych tych dobrze zaadaptowanych jest dwie piąte (Staszyńska 2005).

Rodzice korzystają z wiedzy konsumenckiej dzieci. Są tacy, którzy stawiając na samodzielność dziecka, obarczają je coraz większą odpowiedzialnością i delegują do wykonywania niektórych „dorosłych” zadań, jak zakupy (jest to charakterystyczne dla rodzin niepełnych; Gunter, Furnham 1998, s. 54). Inna grupa rodziców podczas dokonywania zakupów korzysta $z$ rady dzieci. Zdaniem marketerów, rodzice konsultują zakupy z dziećmi w okresie średniego dzieciństwa z powodów pragmatycznych, jak: pewność, że zakup będzie trafiony, chęć zaoszczędzenia czasu czy własne lenistwo. Nastolatki zostają opiniodawcami, ponieważ są traktowane jako wiarygodne źródło informacji na przykład przy zakupie sprzętu elektronicznego (Raport IPSOS 2005). Temu odwróceniu ról społecznych, czyli wejściu dziecka w rolę doradcy, a rodzica w rolę beneficjenta, sprzyja częsty udział dzieci w zakupach dorosłych. W badaniach $37 \%$ rodziców 
Segmentacja konsumentów (w \%)

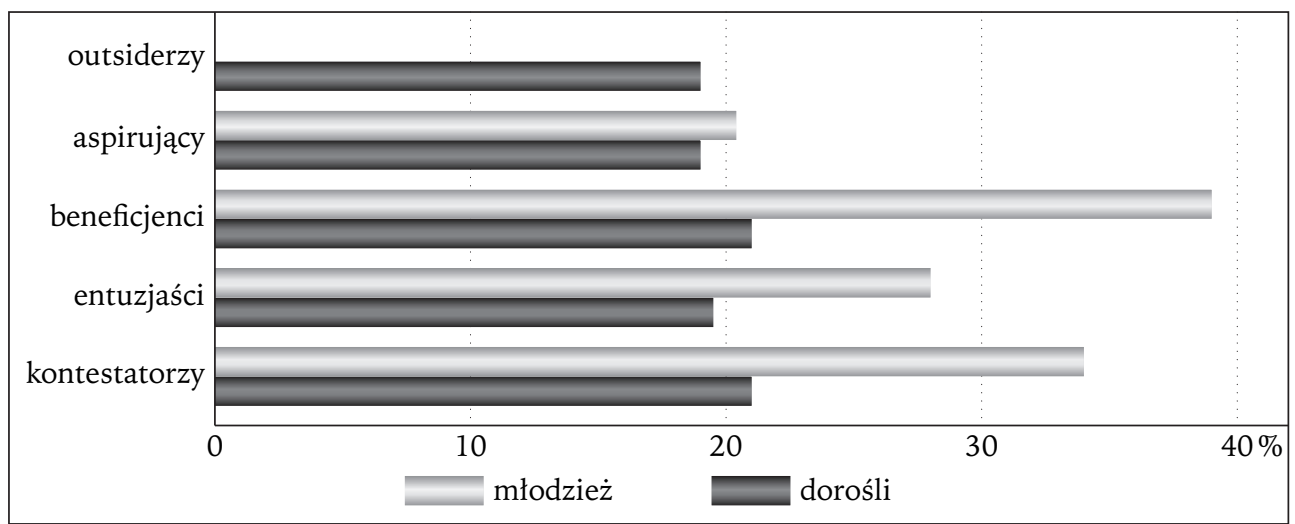

Źródło: opracowanie własne na podstawie Raportu UOKiK „Reklama a konsument”, 2004.

deklaruje, że bardzo często spędza czas z dziećmi na zakupach (Raport TNS-OBOP 2004). Zdaniem 37,4\% dzieci rodzice pytają ich o zdanie przy drogich zakupach, a 32,8\% deklaruje, że doradzają rodzicom (Giza-Poleszczuk 2006). Dzieci najczęściej mają wpływ na wybór marek jogurtów i serków (77\%), napojów gazowanych $(70 \%)$, płatków śniadaniowych $(69 \%)$ oraz odzieży i obuwia dla siebie (64\%) (Raport IPSOS 2008). Z kolei dzieci w wieku od 11 do 18 lat pełnią rolę doradców zakupach telefonów komórkowych (55\%), komputerów (37\%) i gier komputerowych (50\%) (Raport IPSOS 2005).

Przejmowanie roli doradcy w kwestii zakupów potwierdza tezę o zjawisku doroślenia dzieci. Jednak zależności w rodzinie nie są jednoznaczne. Jak pokazały badania trójetapowego procesu decyzyjnego, dzieci faktycznie mają udział $\mathrm{w}$ podejmowaniu przez dorosłych decyzji konsumenckich, ale ograniczony, na przykład nie biorą udziału w decyzjach finansowych. Największy wkład mają $\mathrm{w}$ początkowe etapy procesu decyzyjnego, dalej ich zaangażowanie $\mathrm{w}$ analizę, porównywanie i ocenę oferty rynkowej słabnie, a udział w decyzji ostatecznej jest niewielki. To rodzice ponoszą większą odpowiedzialność za zakupy i wydatki przeznaczone na tzw. produkty wysoko angażujące (Gunter, Furnham 1998, s. 56).

\section{Dziecko inwestor/inwestycja}

Podejmowaną przez dziecko rolę inwestora (inwestycji) rozumie się dwojako: jako „kosztorysowanie rodzicielstwa” i wykreowanie konsumenta przyszłości.

Pojęcie „kosztorysowanie rodzicielstwa” koresponduje z dosadnymi określeniami „makdonaldyzacja ciąży”, „wybór idealnego dziecka” czy „makdonal- 
dyzacja porodu" (Ritzer 2000, s. 253), stosowanymi w krytyce komercyjnych ujęć ważnych wydarzeń życiowych w społeczeństwach konsumpcyjnych. Jest to rodzaj redefinicji macierzyństwa i ojcostwa w kategoriach rynkowych (Halawa 2006). Utożsamianie dziecka $z$ inwestycją, która obejmuje koszty, jakie poniesie rodzic zaspokajając potrzeby swojego dziecka, następuje, po pierwsze, za sprawą marketingu kierowanego do rodziców (tzw. marketing parentingowy), którzy rozpatrywani są jako nabywcy dziecięcych marek (Linn 2004; por. katalog shoppingowy Dziecko, zakupy i my dla rodziców dzieci do 6 lat); po drugie wpływ ma promowanie tzw. dzieciństwa de luxe, co polega na wprowadzaniu w świat dzieci standardów i wartości tworzonych i przeżywanych przez osoby dorosłe, a sprowadza się do kupowania markowych i luksusowych akcesoriów dziecięcych (Krawczyk 2008).

Jeśli chodzi o wykreowanie przyszłego konsumenta, to inwestycja dotyczy tzw. rynku przyszłości (future market) (McNeal 1998). Dzieci przy takim podejściu są potencjalnymi konsumentami (kids-as-a-future-market), de facto będą nimi dopiero $\mathrm{w}$ okresie dorosłości, kiedy zaczną podejmować świadome decyzje dotyczące zakupów. U podstaw leży założenie, że wybór (wykreowanie) marki w dzieciństwie zaowocuje przywiązaniem i lojalnością wobec niej w przyszłości (por. np. McNeal 1998). Wachlarz zabiegów marketingowych, które mają w celu pozyskanie przyszłych konsumentów, jest bardzo bogaty. Należą do nich działania takie jak: kluby członkowskie dla dzieci (np. Toyota Kid's Club; Bogunia-Borowska 2006), sampling, czyli rozdawanie próbek produktów (np. Paka-przedszkolaka; Halawa 2006), zabawki - miniaturki produktów dla dorosłych (np. samochodziki rzeczywistych marek) czy programy lojalnościowe (np. Delta Air Lines rozpoczęła Fantastic Flyer program kierowany do dzieci w wieku 7-14; McNeal 1998). Na podobnej zasadzie działa tzw. marketing edukacyjny „za przyzwoleniem”, który obejmuje akcje promocyjne na terenie placówek oświatowych (np. akcja Volkswagena „Bezpieczna droga” w przedszkolach; Jasielska 2009). Zorientowany na przyszłość jest także ekomarketing, który wykorzystuje modę na ekologię, a ekoprodukt jest promowany jako produkt, który zdominuje przyszłość, warto więc się do niego już przyzwyczaić (Pondel 2007). Odmienną konwencję na rynku przyszłym wykorzystują firmy stosujące tzw. reklamę familijną z wizerunkiem emocjonalnego ciepła (emotional advertising appeals). Pojawia się w niej cała rodzina lub wybrani jej członkowie, na przykład dziadek z wnukiem, cieszący się lub dzielący określonym produktem (np. czekoladki Merci). Uzupełnieniem takiej formy promocji jest marketing od kołyski po grób (cradle-to-grave marketing; Linn 2004), ponieważ niekiedy firma nie wie, jakie produkty będzie sprzedawała za 10-20 lat, ale wie, że będą one sygnowane firmową nazwą, która ma się odpowiednio kojarzyć (np. Coca-Cola Company wykorzystuje wizerunek tzw. bohatera wspólnego, czyli wielopokoleniowego, rozpoznawanego przez dziadków, rodziców i dzieci - Świętego Mikołaja). 


\section{PODSUMOWANIE — DROGI PRZYSZŁYCH ODDZIAŁYWAŃ}

Tematem przewodnim tych rozważań była charakterystyka zmian, które zachodzą równolegle w dwóch grupach wiekowych - dzieci i dorosłych. Obserwuje się społeczno-kulturową "amputację” cech charakterystycznych dla dzieciństwa i dorosłości, czemu towarzyszy „imputacja” tych cech grupom pokoleniowo przeciwstawnym. Za zaistnienie tego zjawiska odpowiedzialne są wzmacniające się procesy infantylizacji kulturowej i komercjalizacji dzieciństwa. Prognozując przyszłość można wskazać kilka potencjalnych konsekwencji realizacji tych tendencji. Prawdopodobnie nastąpi dalsze zamazanie tradycyjnie pojętych ról społecznych. Dorośli staną się mniej odpowiedzialni i mniej wytrwali, pogłębi się proces zanikania rodzicielstwa (White 2006). $Z$ kolei dzieci, niegotowe do realizacji standardów dorosłości, będą podatne na manipulację i wykorzystanie. Złagodzeniu ulegnie prawdopodobnie kontestowanie dorosłości, gdy punkty zwrotne w rozwoju tożsamości, jak młodzieńczy bunt czy utrata dziecięcej niewinności, zostaną skomercjalizowane (Lisowska-Magdziarz 2000). Producenci będą nadal wprowadzać na rynek i promować produkty i usługi przeznaczone dla nowych grup konsumentów i wykorzystywać sprzyjającą koniunkturę (Hajdas 2006), jednak programy marketingowe, które promują wartości dorosłe u dzieci i nastolatków, mogą być szkodliwe dla społeczeństwa jako całości, na przykład promocja swobody seksualnej (Zurbriggen i in. 2007). Podobnie można oceniać dorosłych kreowanych na dzieci, na przykład mężczyzn indolentnych w zakresie konsumpcji (Szlendak 2005).

Aby w pełni zarysować omawiane zagadnienie, należałoby przedstawić zabiegi, jakie można podjąć w celu dokonania powtórnej polaryzacji cech przedstawionych grup. Punktem wyjścia jest fakt, że to osoby dorosłe planują działania marketingowe, wprowadzają na rynek określone produkty, tworzą kampanie reklamowe, aranżują sytuacje konsumenckie itp., przez co ponoszą pełną odpowiedzialność za kreowanie zarówno dojrzałych, jak i młodych konsumentów (por. Jasielska, Maksymiuk 2010). Punktem zwrotnym zaś jest animowanie ruchu konsumenckiego i tworzenie grup nacisku, ponieważ „... dopóki nie weźmiemy sprawy w swoje ręce, dopóty supermarkety, a nawet małe sklepiki osiedlowe, będą z naszymi dziećmi (a za sprawą ich języków również i nami) robiły, co chciały" (Szlendak 2005, s. 43). Inicjatywa oddolna organizacji konsumenckich $\mathrm{w}$ połączeniu $z$ branżą reklamową realizującą standardy odpowiedzialności społecznej mogą przyczynić się do wprowadzenia potrzebnej legislacji, na przykład dotyczącej umieszczania automatów sprzedających napoje i słodycze na terenie placówek oświatowych czy reklamy kierowanej do dzieci. Punktem krytycznym może być zaangażowanie się osób dorosłych $w$ aktywność na wzór ruchu społecznego na rzecz "upraszczania życia” (voluntary simplicity movement) (zob. Szlendak 2005). Członkowie ruchu świadomie rezygnują z kariery, nadgodzin czy nałogowych zakupów, aby przeciwdziałać nadmiernej konsumpcji. Zmiany można wprowadzać także wykorzystując wiedzę psychologiczną w mo- 
delach ekonomicznych i biznesowych. Przykładami takich działań są: zwiększanie heterogeniczności grup konsumentów przez uwzględnienie $\mathrm{w}$ ich opisie takich zmiennych jak cechy osobowości i doświadczenia (Ho, Lim, Camerer 2006) czy opracowanie modelu zakupu zabawki uwzględniającego jej tzw. potencjał edukacyjny (Hirsh-Pasek, Golinkoff 2006). Znaczący udział w zmianie będzie też miała systematyczna edukacja konsumencka zarówno dzieci, jak i dorosłych (Dąbrowska, Janoś-Kresło, Ozimek 2005). Dorośli, którym brakuje wiedzy, sami popełniają „dziecięce” błędy jako konsumenci, na przykład dokonują zakupów impulsywnych czy nie szukają pełnej informacji handlowej itp. Przypominając dane, które mówią o wyższych umiejętnościach konsumenckich młodzieży, a także zasadę, że dla zachowania rodzicielskiego autorytetu ważne jest, aby przejawiać kompetencje w wielu codziennych sytuacjach, warto podejmować $\mathrm{w}$ rodzinie wspólne wysiłki edukacyjne.

Być może zaproponowane remedia: wzrost świadomości konsumenckiej, uwzględnianie wiedzy $z$ innych dziedzin $w$ modelach marketingowych i rodzinna edukacja konsumencka oraz w ogóle analiza dyskutowanej tematyki przyczynią się do przywrócenia naturalnego porządku w omówionych segmentach zbiorowości konsumentów - to znaczy infantylnych dzieci i dojrzałych dorosłych.

\section{BIBLIOGRAFIA}

Barber Benjamin R., 2008, Skonsumowani. Jak rynek psuje dzieci, infantylizuje dorostych i potyka obywateli, tłum. Hanna Jankowska, Muza, Warszawa.

Bogunia-Borowska Małgorzata, 2006, Infantylizacja kulturowa. Adolescencja dzieci oraz infantylizacja dorostych, w: Małgorzata Bogunia-Borowska (red.), Dziecko w świecie mediów $i$ konsumpcji, Wydawnictwo Uniwersytetu Jagiellońskiego, Kraków.

Buckleitner Warren, 2001, Getting Smart on Smart Toy: Ten Tips for Spotting the Winners and Losers, „Children's Software Revue”, nr 7/8.

Buijzen Moniek, Valkenburg Patti M., 2005, Parental Mediation of Undesired Advertising Effects, ,Journal of Broadcasting \& Electronic Media", t. 49, s. 153-165.

Comstock George, Scharrer Erica, 2007, Media and the American Child, Elsevier Science Ltd., Oxford.

Dąbrowska Anna, Janoś-Kresło Mirosława, Ozimek Irena, 2005, Ochrona i edukacja konsumentów we wspótczesnej gospodarce rynkowej, PWE, Warszawa.

Dolacka-Gasparska Maria, 2005, Dzialalność telewizji publicznej na rzecz poprawności jezykowej ze szczególnym uwzględnieniem języka reklamy, w: Andrzej Markowski (red.), Sprawozdanie o stanie ochrony jezzyka polskiego za lata 2003-2004, www.senat.gov.pl/k5/dok/dr/900/a/943.pdf [10.06.2008].

Erikson Erik H., 1997, Dzieciństwo i społeczeństwo, tłum. Przemysław Hejmej, Rebis, Poznań.

Foehr Ulla G., 2006, Media Multitasking among American Youth: Prevalence, Predictors and Pairings, The Henry J. Kaiser Family Foundation, Washington.

Giza-Poleszczuk Anna, 2006, „W krainie konsumpcji”. Referat wygłoszony na konferencji „Moje konsumenckie ABC”, Lublin, 6 kwietnia 2006. 
Gunter Barrie, Furnham Adrian, 1998, Children as Consumers: A Psychological Analysis of the Young People's Market, Routledge, London-New York.

Hajdas Monika, 2006, Konsument bez metryki, „Marketing w Praktyce”, nr 4.

Halawa Mateusz, 2006, Komercjalizacja dziecinstwa. Kosztorysowanie rodzicielstwa, w: Małgorzata Bogunia-Borowska (red.), Dziecko w świecie mediów i konsumpcji, Wydawnictwo Uniwersytetu Jagiellońskiego, Kraków.

Hirsh-Pasek Kathy, Golinkoff Roberta M., 2006, How To Choose Toys for Your Baby, w: Samantha Ettus (red.), The Experts' Guide to the Baby Years, Random House, New York.

Ho Teck H., Lim Noah, Camerer Colin F., 2006, How „Psychological” Should Economic and Marketing Models Be?, „Journal of Marketing Research”, t. 43, s. 341-344.

James Muriel, Jongeward Dorothy, 2003, Narodzić się, by wygrać. Analiza transakcyjna na co dzień, tłum. Anna Suchańska, Rebis, Poznań.

Jasielska Aleksandra, 2009, „Infantylni rodzice vs. poważne dzieci. O wzajemnych relacjach w świecie reklamy”. Referat wygłoszony na XVIII Ogólnopolskiej Konferencji Psychologii Rozwojowej „Rozwój człowieka w kontekście przemian cywilizacyjnych”, Wrocław, 14-16 czerwca 2009.

Jasielska Aleksandra, Kaczmarek Lech, 2008, „Korzyści edukacyjne z zabawek interaktywnych - raport z badania" (tekst niepublikowany).

Jasielska Aleksandra, Maksymiuk Renata A., 2010, Dorośli reklamuja, dzieci kupuja. Kindermarketing i psychologia, Scholar, Warszawa.

Kolańczyk Alina, 1999, Czuję - myśle — jestem, Gdańskie Wydawnictwo Psychologiczne, Gdańsk.

Kossowski Paweł, 1999, Dziecko i reklama telewizyjna, Wydawnictwo Akademickie „Żak”, Gdańsk.

Krawczyk Agnieszka, 2008, Dzieciństwo w wersji de luxe, „Marketing przy Kawie”, nr 208, www.marketing-news.pl/theme.php?art =719 [28.12.2008].

Kunkel Dale i in., 2004, Report of the APA Task Force on Advertising and Children. Section: Psychological Issues in the Increasing Commercialization of Childhood, http://www.apa.org/releases/childrenads.pdf [20.05.2008].

Lindstrom Martin, 2005, Dziecko reklamy, tłum. Agnieszka Monika Kawalec, Świat Książki, Warszawa.

Linn Susan, 2004, Consuming Kids: The Hostile Takeover of Childhood, The New Press, New York-London.

Lisowska-Magdziarz Małgorzata, 2000, Bunt na sprzedaż. Przemyst muzyczny — reklama semiotyka, Wydawnictwo Uniwersytetu Jagiellońskiego, Kraków.

Maison Dominika, 1999, Aktywator kontra ceramidy, „Charaktery”, nr 7.

Maison Dominika, Rudzińska Joanna, 2009, Jak z pieniędzmi radzą sobie dzieci?, „Marketing w Praktyce", nr 5.

Maruszewski Tomasz, 1996, Psychologia poznawcza, Polskie Wydawnictwo Semiotyczne, Warszawa.

McNeal James U., 1992, Kids as Customers: A Handbook of Marketing to Children, Lexington Books, New York.

McNeal James U., 1998, Kids' markets, „American Demographics”, t. 20, s. 36-42.

Moen Phyllis, Spencer Donna, 2006, Converging Divergences in Age, Gender, Health, and Well-Being: Strategic Selection in the Third Age, w: Robert H. Binstock i in. (red.), Handbook of Aging and the Social Sciences, Elsevier, Oxford. 
Nęcka Edward, 2001, Psychologia twórczości, Gdańskie Wydawnictwo Psychologiczne, Gdańsk.

Nęcka Edward, Orzechowski Jarosław, Szymura Błażej, 2006, Psychologia poznawcza, Wydawnictwo Naukowe PWN, Warszawa.

Pondel Hanna, 2007, Wykorzystanie koncepcji ekomarketingu w rynkowej walce o klienta, „Zeszyty Naukowe Gnieźnieńskiej Wyższej Szkoły Humanistyczno-Menedżerskiej”, nr 1.

Postman Neil, 1994, The Disappearance of Childhood, Vintage Books, New York.

Ranking zabawek, 2006, Duracell pyta dzieci, „Marketing przy Kawie”, nr 141, http://www.marketing-news.pl/theme.php?art $=447$ [06.02.2008].

Raport IPSOS, 2005, Kieszonkowe naszych dzieci, www.ipsos.pl/new/3_1_035.html [21.04.2009].

Raport IPSOS, 2008, Dzieci maja pieniądze, www.ipsos.pl/new/3_1_039.html [10.07. 2009].

Raport TNS-OBOP, 2004, Lubimy rozmawiać z dziećmi - badanie zrealizowane na zlecenie Fundacji Komunikacji Społecznej w ramach kampanii „Tata i ja”, www.tns-global.pl/2004-06\#753 [03.08.2009].

Raport UOKiK, 2004, Reklama a konsument, www.uokik.gov.pl/pl/informacja_i_edukacja /badania_opinii_spolecznej/ochrona_konsumentow [15.01.2009].

Ritzer George, 2000, Makdonaldyzacja spō̄eczeństwa, tłum. Sławomir Magala, Muza, Warszawa.

Ryłko-Kurpiewska Anna, 1997, Bohater z bajki, „Aida Media”, nr 12.

Schor Juliet B., 2004, Born to Buy, Scribner, New York.

Staszyńska Katarzyna M., 2005, Różne twarze polskich konsumentów, www.euroinfo.org.pl /index.php?option $=$ com_content $\&$ task $=$ view\&id $=149 \&$ Itemid $=66$ [23.03.2009].

Szlendak Tomasz, 2005, Leniwe maskotki i rekiny na smyczy. W co kultura konsumpcyjna przemienita mężczyzn $i$ kobiety, Jacek Santorski \& Co, Warszawa.

Szlendak Tomasz, Kozłowski Tomasz, 2008, Naga matpa przed telewizorem. Popkultura $w$ świetle psychologii ewolucyjnej, Wydawnictwa Akademickie i Profesjonalne, Warszawa.

Wenglorz Justyna (red.), 2006, Wykorzystanie nowych mediów przez młodzież $w$ Polsce wyniki międzynarodowego projektu badawczego Mediappro, Nowa Era, Warszawa.

White James E., 2006, The Disappearance of Childhood... and More, „Serious Times”, nr 1. Zurbriggen Eileen i in., 2007, Report of the APA Task Force on the Sexualization of Girls, http://www.apa.org/pi/wpo/sexualization.html [15.04.2009].

\section{THE INFLUENCE OF INFANTILE CULTURE ON THE SOCIETY OF CONSUMERS}

\section{Summary}

Growing consumption contributes to the creation of new consumer groups - childish parents and commercialized children. This process of turning adults into children and vice versa is reflected in dynamically developing marketing and advertising activities aimed at both target groups. Regardless of the age difference, for market experts they both present similar market behavior patterns. Traditional values have been reversed. Adverts emphasizing speed and facility are aimed at adults whereas advertising sophistication and responsibility is aimed at children. This mainly refers to some forms of 
promotion activity within primary, influence and future markets. Systematic consumer education for both groups seems to be a way to re-introduce a division into adults and children. It is impossible to educate children in the area in which parents and other adults are incompetent.

\section{Key words/słowa kluczowe}

consumerism / konsumeryzm; commercialization of childhood / komercjalizacja dzieciństwa; infantilization of adults / infantylizacja dorosłych; primary market / rynek pierwotny, influence market / rynek wplywu; future market / rynek przyszły; consumer education / edukacja konsumencka 